\title{
Children Hearing System Sebagai Ide Pembaharuan Sistem Peradilan Pidana Anak di Indonesia
}

\author{
Fifid Bramita ${ }^{1}$, Irma Cahyaningtyas ${ }^{2}$
}

${ }_{1}$ Program Studi Magister Ilmu Hukum Universitas Diponegoro,E-mail:fifidbramita18@gmail.com ${ }^{2}$ Fakultas Hukum Universitas Diponegoro, E-mail: irmacahyaningtyas@yahoo.com

\begin{tabular}{l}
\hline Info Artikel \\
\hline Masuk: 16 Nopember 2018 \\
Diterima: 17 Desember 2018 \\
Terbit: 31 Desember 2018 \\
Keywords: \\
Restorative Justice; Children \\
Hearing; Idea; Reform; Juvenile \\
Justice System \\
\\
\\
\\
Kate kunci: \\
Restorative Justice; Children \\
Hearing; Ide, Pembaharuan, \\
Sistem Peradilan Pidana Anak \\
Corresponding Author: \\
Email: \\
fifidbramita18@gmail.com \\
DOI: \\
10.24843/JMHU.2018.v07.i04. \\
p08 \\
\end{tabular}

\begin{abstract}
Children as the next generation must be protected by their rights. discussing the issue of a policy for resolving child cases is also inseparable from efforts to combat child crime. Diversion as an effort to achieve restorative justice only reaches repressive efforts that focus on crime prevention efforts after the crime occurs and does not reach preventive measures (prevention/deterrence/ control) before the crime occurs. If we pay attention, this is where the rigidity of diversion is seen. Therefore a new idea is needed to optimize diversion such as the Children Hearing System. The Children Hearing System is a typical Scottish treatment and justice system for children and adolescents. In the Children hearing System, Children as a pepretors as well as children as victims are not directly faced with the judicial process. The study aims to find out how to Children's Hearing System As An Idea Of Reform In The Criminal Justice System Of Children In Indonesia and Children's Hearing System As Efforts To Achieve Restorative Justice In The Criminal Justice System Of Children In Indonesia. The author uses the Normative Juridical research method in assessing the criminal justice system of children through the Children Hearing System. Research results showed that the Children Hearing System can be carried out as an idea of renewal in the child justice system in Indonesia as optimization of diversion to achieve restorative justice. This is because the Children Hearing System can reach repressive efforts and preventive efforts in resolving child cases.
\end{abstract}

\begin{tabular}{l} 
Abstrak \\
\hline Anak sebagai generasi penerus bangsa harus dilindungi \\
hak-haknya. Membicarakan masalah kebijakan \\
penyelesaian perkara anak tidak terlepas juga dari upaya \\
penanggulangan kejahatan anak. Diversi sebagai upaya \\
untuk mencapai restorative justice hanya menjangkau \\
upaya represif saja yang menitik beratkan pada \\
penanggulangan kejahatan setelah kejahatan itu terjadi dan \\
tidak menjangkau perayarantif \\
(pencegahan/penangkalan/pengendalian) preventif \\
kejahatan itu terjadi. Jika kita lihat, di sinilah terlihat \\
kekakuan diversi. Oleh karenanya diperlukan suatu ide \\
baru untuk mengoptimalkan diversi yakni seperti Children \\
Hearing System. Children Hearing System adalah sistem
\end{tabular}


perawatan dan keadilan khas Skotlandia untuk anak-anak dan remaja. Dalam Children hearing System, anak yang berhadapan dengan hukum tidak langsung berhadapan dengan proses peradilan. Penelitian bertujuan untuk meneliti lebih lanjut kebijakan mengenai Children's Hearing System sebagai ide pembaharuan dalam sistem peradilan pidana anak di indonesia dan kebijakan mengenai ide Children's Hearing System Sebagai Upaya Untuk Mencapai Restorative Justice Di Dalam Sistem Peradilan Pidana Anak Di Indonesia. Penulis menggunakan metode penelitian Yuridis Normatif. Hasil Penelitian menunjukkan bahwa Children Hearing System dapat dijadikan sebagai ide pembaharuan dalam sistem peradilan pidana anak di indonesia sebagai optimalisasi dari diversi untuk mencapai restorative justice. Hal ini dikarenakan Children Hearing System dapat menjangkau upaya represif dan juga upaya preventif dalam menyelesaikan perkara anak.

\section{Pendahuluan}

Anak merupakan sebuah anugerah yang berasal dari Tuhan Yang Maha Esa sebagai generasi penerus bangsa yang masih berada dalam masa perkembangan mental dan fisik. Ada saat-saat dimana anak mengalami masa-masa sulit yang membuat anak dapat melakukan perbuatan yang dapat melanggar hukum. Seorang anak sesuai sifatnya masih memiliki daya nalar yang belum cukup baik untuk membedakan hal-hal baik dan buruk. Tindak pidana yang dilakukan oleh anak pada umumnya adalah merupakan proses meniru ataupun terpengaruh dengan bujuk rayu dari orang dewasa. ${ }^{1}$ Anak yang melakukan pelanggaran terhadap hukum tidak layak untuk dihukum dan dimasukkan ke dalam sel-sel penjara. Anak bukanlah untuk dihukum, melainkan dapat diberikan bimbingan dan pembinaan, sehingga anak dapat tumbuh dan berkembang seperti anak normal yang sehat, cerdas dan masih dapat menikmati masa anak-anak secara utuh.

Hak-hak anak secara tegas dinyatakan dalam konstitusi yakni pada Pasal 28 B Ayat 2 Undang-Undang Dasar Negara Republik Indonesia 1945, bahwa negara menjamin setiap hak anak atas kelangsungan hidup, tumbuh dan berkembang, serta berhak atas perlindungan dari kekerasan dan diskriminasi. Segala upaya harus dilakukan untuk melindungi hak-hak anak agar anak tidak mendapat kekerasan dan diskriminasi serta terjerumus untuk melakukan perbuatan yang melanggar hukum yang nantinya akan merugikan anak itu sendiri.

Berdasarkan pasal diatas, negara dan masyarakat berkewajiban untuk memberikan perlindungan terhadap hak anak. sejalan dengan hal tersebut, berdasarkan Konvensi

1 Sari, M.A.C.M (2013). Diversi Dalam Sistem Peradilan Pidana Anak di Indonesia. Jurnal Magister Hukum Udayana (Udayana Master Law Journal). 2(1), https://doi.org/10.24843/JMHU.2013.v02.i01.p05. h. 2. 
Hak Anak, ada 4 prinsip umum perlindungan anak yang menjadi dasar bagi setiap negara dalam menyelenggarakan perlindungan anak, antara lain: ${ }^{2}$

1. Prinsip Non Diskriminasi

2. Prinsip Kepentingan Terbaik Baik Bagi Anak

3. Prinsip Hak Hidup, Kelangsungan Hidup, dan Perkembangan

4. Prinsip Penghargaan Terhadap Pendapat anak.

Anak dalam masa-masa pertumbuhan dan perkembangannya akan sangat rentan untuk terpengaruh dengan situasi dan kondisi lingkungan sosial di sekitarnya. Perbuatan salah yang dilakukan oleh anak yang di sebabkan karena tidak adanya pengarahan dan pembimbingan yang benar dapat berubah menjadi "kenakalan anak atau kejahatan anak (juvenile delinquency)". Romli Atmasasmita menyatakan bahwa Juvenile Delinquency ialah $: 3$

"Setiap Perbuatan atau tingkah laku seseorang anak di bawah umur 18 tahun dan belum kawin yang merupakan pelanggaran terhadap norma-norma hukum yang berlaku serta dapat membahayakan perkembangan pribadi si anak yang bersangkutan."

Kejahatan anak atau pelanggaran hukum yang dilakukan oleh anak pada hakikatnya merupakan hasil dari keterbatasan anak dalam memahami dan melindungi diri dari berbagai pengaruh sistem yang ada, yang pada akhirnya dapat menyebabkan anak masuk dalam sistem peradilan pidana anak ${ }^{4}$. Pasal 1 Angka 1 Undang-Undang Nomor 11 Tahun 2012 Tentang Sistem Peradilan Pidana Anak menyatakan, Sistem peradilan pidana anak adalah keseluruhan proses penyelesaian perkara Anak yang berhadapan dengan hukum, mulai tahap penyelidikan sampai dengan tahap pembimbingan setelah menjalani pidana. Di dalam sistem peradilan pidana anak, terdapat aktivitas pemeriksaan dan pemutusan perkara yang menyangkut kepentingan anak, yaitu segala aktivitas yang dilakukan oleh polisi, jaksa, hakim dan pejabat lain, harus didasarkan pada suatu prinsip ialah demi kesejahteraan anak dan kepentingan anak. ${ }^{5}$ Proses peradilan ini akan menimbulkan dampak psikologis yang merugikan bagi anak. mereka akan mengalami tekanan dan stigmatisasi selama menjalani peradilan. ${ }^{6}$

Perlindungan anak sudah memiliki beberapa aturan hukum yang cukup seperti Undang-undang Nomor 4 Tahun 1979 Tentang Kesejahteraan anak, Undang-undang Nomor 11 Tahun 2012 Tentang Sistem Peradilan Pidana Anak, Undang-Undang Nomor 10 Tahun 2012 Tentang Pengesahan Protokol Opsional Konvensi Hak Anak

2 Djamil, M. N. (2013). Anak Bukan Untuk Dihukum: Catatan Pembahasan UU Sistem Peradilan Pidana Anak (UU-SPPA). Jakarta: Sinar Grafika, h. 29-31.

3 Nashriana. (2011). Perlindungan Hukum Pidana bagi Anak di Indonesia. Jakarta: Raja Grafindo Persada, h. 29.

4 Marlina. (2012). Peradilan Pidana Anak Di Indonesia, Pengembangan Konsep Diversi dan Restorative Justice. Medan: PT Refika Aditama, h. XV.

5 Wahyudi, S. (2009). Penegakkan Peradilan Pidana Anak Dengan Pendekatan Hukum Progresif Dalam Rangka Perlindungan Anak. Jurnal Dinamika Hukum, 9(1), http://dx.doi.org/10.20884/1.jdh.2009.9.1.52. h. 29.

6 Rochaeti, N. (2015). Implementasi Keadilan Restoratif dan Pluralisme Hukum Dalam Sistem Peradilan Pidana Anak Di Indonesia. Jurnal Masalah-Masalah Hukum, 44(2), http://dx.doi.org/10.14710/mmh.44.2.2015.150-160. h. 150. 
Mengenai Penjualan Anak, Prostitusi Anak, Undang-Undang Nomor 9 Tahun 2012 Tentang Pengesahan Protokol Opsional Konvensi Hak Anak mengenai Keterlibatan anak dalam Konflik Bersenjata, Undang-undang Nomor 1 Tahun 2000 Tentang Konvensi ILO No.182 Mengenai Pelarangan dan Tindakan Kekerasan, Undang-undang Nomor 35 Tahun 2014 jo Undang-undang Nomor 23 Tahun 2002 tentang Perlindungan Anak, Undang-undang Nomor 21 Tahun 2007 Tentang Pemberantasan Tindak Pidana Perdagangan Orang. Undang-undang Nomor 23 Tahun 2004 Tentang Penghapusan Kekerasan dalam Rumah Tangga Sera Undang-undang Nomor 31 Tahun 2014 Tentang Perlindungan Saksi dan Korban. Keseluruhan regulasi ini bertujuan untuk melindungi hak-hak anak itu sendiri.

Sistem peradilan pidana untuk anak harus dilaksanakan dengan memperhatikan kepentingan yang terbaik bagi anak. Berdasarkan penjelasan dari Pasal 2 huruf $\mathrm{d}$ Undang-undang Nomor 11 Tahun 2012 Tentang Sistem Peradilan Pidana Anak, kepentingan yang terbaik bagi anak itu sendiri adalah segala pengambilan keputusan harus selalu mempertimbangkan kelangsungan hidup dan tumbuh kembang anak. Demi mempertimbangkan kelangsungan hidup dan tumbuh kembang anak, maka Undang-Undang Nomor 11 Tahun 2012 Tentang Sistem Peradilan Pidana Anak dalam Pasal 2 huruf i telah menyatakan bahwa perampasan kemerdekaan dan pemidanaan sebagai upaya terakhir.

Maksud dari perampasan kemerdekaan sebagai upaya terakhir adalah pada dasarnya anak tidak dapat dirampas kemerdekaannya, kecuali terpaksa guna kepentingan penyelesaian perkara. Hal ini ditujukan agar anak dapat terhindar dari stigma sosial dan dampak buruk yang ditimbulkan dari adanya sanksi perampasan kemerdekaan.

Peradilan anak pada hakikatnya diselenggarakan dengan tujuan untuk mendidik kembali dan memperbaiki sikap juga perilaku anak sehingga ia dapat meninggalkan perilaku buruk yang selama ini telah dilakukannya.7 Penyelesaian perkara anak yang berkonflik dengan hukum harus tetap mengutamakan prinsip-prinsip hak anak, dimana penangkapan, penahanan, atau bahkan pemenjaraan terhadap anak hanya dilakukan sebagai upaya terakhir (ultimum remedium) dan dalam jangka waktu yang sesingkatsingkatnya. ${ }^{8}$. Bagaimana hal tersebut dapat terwujud apabila masih terdapat beberapa kendala dalam penanganan anak yang berhadapan dengan hukum. Pada kenyataannya penanganan anak yang berhadapan dengan hukum dalam peradilan pidana masih terdapat beberapa kendala, yaitu: ${ }^{9}$

a. Penerapan hukum belum sepenuhnya sesuai dengan ketentuan undang-undang yang berlaku.

b. Belum ada persamaan persepsi antar aparat penegak hukum mengenai penanganan $\mathrm{ABH}$ untuk kepentingan terbaik bagi anak.

c. Terbatasnya sarana dan prasarana penanganan bagi anak yang berhadapan dengan hukum selama proses pengadilan (pra dan pasca putusan pengadilan)

7 Gultom, M. (2008). Perlindungan Hukum terhadap anak dalam sistem peradilan pidana anak diindonesia, Bandung: Refika Aditama, h. 77.

8 Gilang Ramadhan Suharto. (2015). Restorative Justice Peradilan Pidana Anak di Indonesia. Lex Crimen, 4(1), h. 35.

9 Rochaeti, N. Op., Cit, h. 150-151. 
d. Koordinasi antara aparat penegak hukum (polisi, jaksa, hakim, advokat, bapas, rutas, lapas) masih tersendat-sendat karena ego sektoral.

Banyaknya kendala yang terdapat dalam penanganan anak yang berhadapan dengan hukum tersebut di dalam sistem peradilan pidana anak akan sangat berpengaruh terhadap berhasil atau tidaknya penyelesaian perkara anak menggunakan diversi sebagai upaya untuk mencapai restorative justice. Diversi adalah suatu pengalihan penyelesaian kasus-kasus anak yang diduga melakukan tindak pidana tertentu dari proses pidana formal ke penyelesaian damai antara tersangka/terdakwa/pelaku tindak pidana dengan korban yang difasilitasi oleh keluarga dan/atau masyarakat, pembimbing kemasyarakatan anak, polisi, jaksa atau hakim ${ }^{10}$. Akan tetapi, tidak ada angka statistik resmi mengenai tingkat keberhasilan musyawarah (Diversi) dalam menyelesaikan konflik di Indonesia. Restorative Justice sendiri hingga saat ini masih dievaluasi, sebagian menunjukkan keberhasilan, sebagian lainnya berakhir dengan ketidakpuasan. Satu hal yang pasti adalah restorative justice bukanlah obat untuk segala masalah (panacea), tetapi mengingat sistem peradilan pidana yang sekarang memiliki dampak negatif bagi anak, penggunaan restorative justice bagi anak menjadi pilihan yang terbaik untuk menangani anak yang berhadapan dengan hukum. ${ }^{11}$

Berdasarkan hal diatas, membicarakan masalah kebijakan penyelesaian perkara anak tidak terlepas juga dari upaya penanggulangan kejahatan anak. Diversi sebagai upaya untuk mencapai restorative justice hanya menjangkau upaya represif saja yang menitik beratkan pada upaya penanggulangan kejahatan setelah kejahatan itu terjadi dan tidak menjangkau upaya preventif (pencegahan/penangkalan/ pengendalian) sebelum kejahatan itu terjadi. Jika kita perhatikan, di sinilah terlihat kekakuan dari diversi. Selain itu, di dalam pelaksanaan masih terdapat beberapa kendala yakni seperti :12

a. Masih banyak petugas/penegak hukum yang tidak mengetahui, tidak mengerti dan tidak paham tentang keadilan restoratif dan diversi sehingga terjadi perbedaan persepsi dalam pelaksanaannya.

b. Diversi dipahami sebagai ganti rugi (biaya ganti rugi barang yang dicuri, yang rusak, biaya pengobatan, biaya adat dan lain-lain) sehingga tidak tercapai kesepakatan karena angka nominal belum sesuai dengan keinginan korban/keluarga atau anak/keluarga.

c. Perilaku atau tingkat keinginan para penegak hukum yang cenderung belum ingin mewujudkan sesuai tujuan diversi yaitu adanya keberpihakan pada salah atu pihak (korban/pelaku) dan belum mampu berperan sebagai mediator maupun fasilitator.

Berdasarkan hal diatas, untuk itu diperlukan suatu cara mengoptimalisasikan hal tersebut. Saat ini telah ada suatu sistem yang jauh lebih baik, fleksibel dan tidak kaku seperti diversi, yaitu "Children Hearing System" yang ada di Skotlandia. Oleh karenanya, akan lebih baik apabila kita melihat kepada sistem peradilan pidana anak yang ada di Skotlandia, khususnya "Children Hearing System".

10 Djamil, M. N. (2013). Anak Bukan Untuk Dihukum: Catatan Pembahasan UU Sistem Peradilan Pidana Anak (UU-SPPA). Jakarta: Sinar Grafika, h. 137

11 Fathurokhman, F. (2013). Undang-Undang Sistem Peradilan Anak, Pelajaran dari Kearifan Lokal dan Kasus Raju. Kanun Jurnal Ilmu Hukum, 60(XV), h.353

12 Rochaeti, N. Op.,Cit. h. 157. 
Skotlandia telah lama bangga dengan prosedur uniknya yaitu "Children's Hearing system", untuk menangani anak-anak yang memerlukan tindakan wajib intervensi negara dalam kehidupan mereka, entah karena ada perhatian dan perlindungan atau karena mereka telah melakukan tindak pidana. ${ }^{13}$ Pemerintah Skotlandia tidak memiliki pengadilan khusus bagi anak delinkuen. Anak-anak yang melakukan delinquency dibawa ke Children's Hearing System yang tidak memiliki sanksi untuk menghukum mereka. Oleh karena itu, kajian mengenai hal ini patut untuk diperhitungkan dalam sistem peradilan pidana di Indonesia.

Maka berdasarkan uraian dari latar belakang di atas, selanjutnya permasalahan yang akan dibahas di dalam tulisan ini adalah Bagaimana ide Children's Hearing System dapat di implementasikan dalam pembaharuan sistem peradilan pidana anak di indonesia dan Apakah Children's Hearing System dapat dijadikan sebagai sarana untuk mencapai Restorative Justice di dalam sistem peradilan pidana anak di indonesia? Oleh karena itu, Tujuan Penelitian ini ialah untuk meneliti lebih lanjut kebijakan mengenai Children's Hearing System sebagai ide pembaharuan dalam sistem peradilan pidana anak di indonesia dan kebijakan mengenai ide Children's Hearing System Sebagai Upaya Untuk Mencapai Restorative Justice Di Dalam Sistem Peradilan Pidana Anak Di Indonesia.

\section{Metode Penelitian}

Metode penelitian yang digunakan dalam penulisan ini adalah dengan menggunakan metode penelitian Yuridis Normatif. Dimana penelitian hukum normatif ini merupakan penelitian kepustakaan. Studi kepustakaan diperlukan untuk mengumpulkan bahanbahan hukum yang diperlukan, seperti bahan-bahan hukum primer yang meliputi peraturan perundang-undangan yang mengatur tentang sistem peradilan pidana anak dan perlindungan anak, serta peraturan perundang-undangan lain yang terkait tentang pelaksanaan sistem peradilan pidana anak juga perlindungan anak. Bahan-bahan hukum sekunder, seperti buku-buku, karya ilmiah hukum, dan bahan-bahan tertulis lain yang dipakai untuk memberikan penjelasan dari beberapa istilah yang digunakan dalam penulisan ini. Pendekatan- pendekatan yang dilakukan dalam penelitian hukum ini diantaranya Pendekatan Undang-Undang (Statue Approach) dan Pendekatan konseptual (Conceptual Approach) dan Pendekatan Perbandingan (Comperative Approach). Pendekatan Konseptual (Conceptual Approach) dilakukan dengan cara membedah buku-buku yang berkaitan dengan penelitian. Kemudian Pendekatan UndangUndang (Statue Approach) dilakukan dengan cara menelaah berbagai Undang-Undang dan regulasi terkait dengan sistem peradilan pidana anak di indonesia. Dan Pendekatan Perbandingan (Comperative Approach) dilakukan dengan melihat sistem peradilan pidana anak di Skotlandia.

13 Norrie, K. (2000). Human rights challenges to the children's hearing system. Journal of the Law Society of Scotland, 45(4), 19-21 


\section{Hasil dan Pembahasan}

\subsection{Children's Hearing System Sebagai Ide Pembaharuan dalam Sistem Peradilan Pidana Anak di Indonesia}

Penyelenggaraan sistem peradilan pidana anak memiliki tujuan untuk mewujudkan kesejahteraan anak. Hal ini sebagaimana ditegaskan dalam peraturan Perserikatan Bangsa-bangsa (PBB) dalam United Nation Standard Minimum Rules For The Administration Of Juvenile Justice (SMRJJ) atau The Beijing Rules, yang menyatakan bahwa tujuan peradilan anak (Aims Of Juvenile Justice), adalah sebagai berikut ini: ${ }^{14}$

"The juvenile justice system shall emphasize the well-being of the juvenile and shall ensure that any reaction to juvenile offenders shall always be in proportion to the circumstances of both the offenders and the offence.

Dengan demikian, tujuan sistem peradilan pidana anak adalah untuk memajukan kesejahteraan anak (The Promotion Of The Well Being Of The Juvenile) dan memperhatikan prinsip Proporsionalitas (The Principle Of Proportionality. Memajukan kesejahteraan anak merupakan fokus utama (The Main Focus), yakni untuk menghindari penggunaan sanksi pidana yang semata-mata bersifat menghukum (Avoidance Of Marely Punitive Sanction). Tujuan pada prinsip proporsional karena mengekang penggunaan sanksi-sanksi, yang kebanyakan dinyatakan dalam batasan-batasan ganjaran yang setimpal dengan beratnya pelanggaran hukum (Mostly Expressed in terms of just desert in relation to the gravity off the offence). Tetapi juga memperhatikan pada pertimbangan keadaan-keadaan pribadinya (be based on the consideration of personal circumtance). ${ }^{15}$

Children Hearing System merupakan sistem perawatan dan keadilan khas Skotlandia untuk anak-anak dan remaja akibat tidak adanya pengadilan khusus bagi anak delinkuen di Skotlandia. Children Hearing System diperkenalkan oleh peraturan Dinas Pekerjaan Sosial tahun 1968, dan diatur oleh Children Hearing System Act 2011. Hal ini muncul karena adanya kekhawatiran di akhir 1950-an dan awal 1960-an bahwa perubahan diperlukan dalam cara masyarakat menangani anak-anak dan remaja yang kesulitan atau beresiko.

Sebuah Komite dibentuk pada tahun 1960 di bawah Lord Kilbrandon untuk menyelidiki kemungkinan adanya solusi bagi anak yang mengalami masalah. Lord Kilbrandon adalah seorang hakim senior Skotlandia. Anggota komite yang dibentuk oleh Lord Kilbrandon adalah empat hakim perdamaian, empat pengacara, seorang kepala polisi, seorang kepala sekolah, seorang psikiater dan seorang petugas percobaan.

Laporan Kilbrandon mendefinisikan prinsip-prinsip inti yang diwujudkan melalui penciptaan Sistem Dengar Pendapat Anak-Anak ${ }^{16}$ :

- Apakah anak-anak atau remaja yang bermasalah membutuhkan perawatan kebutuhan yang sama dan apakah kebutuhan itu harus dipenuhi.

14 United Nations Standard Minimum Rules for the Administration of Juvenile Justice ("The Beijing Rules") Adopted by General Assembly resolution 40/33 of 29 November 1985 Part one, p. 3.

15 Wahyudi, S. (2011). Implementasi Ide Diversi Dalam Pembaharuan Sistem Peradilan Pidana Anak Di Indonesia. Yogyakarta: Genta Publishing, h. 2.

16 Children's Hearing Skotland, Retrieved from http://www.chscotland.gov.uk/the-childrenshearings-system/ 
- Sangat pentingnya pendekatan preventif, yang melibatkan identifikasi awal dan diagnosis terhadap masalah.

- Apabila bukti-bukti telah terkumpul, fokus sidang harus pada cara terbaik untuk memenuhi kebutuhan anak dan remaja.

- Dalam hal memutuskan bagaimana kebutuhan anak dan remaja yang harus dipenuhi, kesejahteraan anak dan remaja merupakan pertimbangan yang penting.

- Keluarga anak atau remaja harus ikut menjadi bagian dari diskusi mengenai cara terbaik untuk memenuhi kebutuhan anak atau remaja tersebut.

- Langkah-langkah wajib perawatan harus diterapkan hanya dimana kesejahteraan anak atau remaja tidak dapat dijamin.

- Melalui penunjukkan anggota awam, anak satu komunitas lokal remaja harus berpartisipasi dalam keputusan tentang anak-anak atau remaja.

Hingga akhirnya, Pada 15 April 1971 Children's Hearing mengambil alih sebagian besar tanggung jawab pengadilan untuk menangani anak-anak dan orang muda di bawah 16 tahun, dan dalam beberapa kasus di bawah usia 18 tahun, yang melakukan pelanggaran atau yang membutuhkan perawatan dan perlindungan. Cara kerja Children Hearing System adalah ${ }^{17}$ :

1. seorang anak atau remaja dirujuk ke reporter anak,

2. reporter anak memutuskan apakah mereka dapat pergi ke Children Hearing atau tidak.

Tujuan Children Hearing System adalah untuk memastikan keamanan dan kesejahteraan anak-anak dan remaja yang rentan melalui pengambilan keputusan tribunal yang disebut Panel Anak-Anak. Anak-anak dan orang muda yang menghadapi masalah serius dalam hidup mereka diminta untuk pergi ke pertemuan yang disebut Children Hearing. Panel Anak-anak membuat keputusan pada sidang tentang bantuan dan bimbingan yang diperlukan untuk mendukung anak atau orang muda. Keputusan dibuat demi kepentingan terbaik anak atau remaja untuk membantu dan melindungi mereka. Salah satu prinsip dasar dari Children Hearing System adalah bahwa anak-anak dan remaja yang melakukan pelanggaran, dan anak-anak dan remaja yang membutuhkan perawatan dan perlindungan, ditangani dalam sistem yang sama ${ }^{18}$

Prinsip utama dan terpenting adalah bahwa kebutuhan seorang anak harus dinilai sehingga pengobatan yang tepat dapat diterapkan. Ini hanya bisa dicapai dengan pemeriksaan objektif atas semua fakta dan keadaan di sekitarnya. Adalah tidak tepat untuk mengharapkan satu lembaga untuk menentukan fakta yang disengketakan dan menetapkan kebutuhan setiap anak dalam informasi lengkap tentang keadaan pribadi keluarga anak.

Ada banyak alasan berbeda mengapa seorang anak diminta untuk pergi ke sidang (Children Hearing ) yakni adalah ${ }^{19}$ :

- jika orang-orang khawatir tentang keselamatan mereka

- jika mereka mengalami masalah dengan pergi ke sekolah

17 Ibid.

18 Ibid.

19 Ibid 
- jika mereka bermasalah dengan polisi

- jika dikhawatirkan bahwa mereka tidak dirawat dengan baik di rumah

Pada tahap Children's Hearing, diadakan sidang anak-anak atau yang biasanya disebut panel anak-anak adalah pertemuan hukum yang diatur untuk mempertimbangkan dan membuat keputusan tentang anak-anak dan remaja yang mungkin mengalami masalah dalam kehidupan mereka. Children Hearing diadakan secara pribadi dan hanya orangorang yang memiliki hak hukum untuk berada di sana, atau diizinkan untuk berada di sana oleh anggota ketua yang hadir.

Sidang terdiri dari tiga anggota komunitas lokal yang bertindak sebagai anggota tribunal awam, yang disebut anggota panel. Mereka memberikan waktu mereka dengan bebas (mereka tidak dibayar) untuk duduk di sidang. Sidang dilakukan dengan mendengarkan keadaan anak dan kemudian memutuskan apakah tindakan wajib pengawasan diperlukan untuk anak dan, jika demikian tindakan pengawasan yang seperti apa yang seharusnya dilakukan. Para anggota panel melakukan kegiatan pelatihan dan pengembangan pada waktu mereka sendiri untuk memastikan bahwa mereka diperlengkapi untuk membuat keputusan demi kepentingan terbaik anak-anak dan remaja, dengan audiensi yang dilakukan secara adil. ${ }^{20}$ Hasil sidang memuat keputusan berupa:

- Diperlukan atau tidaknya langkah-langkah pengawasan resmi dan wajib dalam menyelesaikan kasus.

- Anggota panel membutuhkan lebih banyak informasi untuk membantu mereka membuat keputusan tentang apa yang terbaik untuk anak-anak dan remaja. Mereka dapat menunda sidang untuk dapat membuat keputusan untuk anak atau remaja jika dalam keadaan mendesak.

- Langkah-langkah wajib pengawasan diperlukan untuk membantu anak-anak atau remaja dengan membuat perintah pengawasan wajib. Dimana anak-anak atau remaja tinggal bersama dengan pengasuh angkat atau kerabat.

Children's Hearing System ini bertujuan untuk menggali setiap informasi dari pihak anak. Hal ini dilakukan oleh anggota panel yang akan menanyakan pertanyaan-pertanyaan untuk memastikan anak mendapatkan bantuan yang benar. Jika anggota panel khawatir tentang anak, mereka mungkin membuat apa yang disebut Perintah Pengawasan Wajib. Perintah pengawasan wajib adalah suatu pengawasan yang melibatkan Departemen Pekerjaan Sosial dan Otoritas Lokal dalam hidup anak dam mereka harus menjaga dan membantu anak.

Sebagian besar anak-anak yang mendapat Pengawasan Wajib tetap tinggal di rumah, tetapi jika anggota panel sangat khawatir tentang keselamatan anak, mereka mungkin memutuskan bahwa anak perlu tinggal di tempat lain untuk sementara waktu agar anak tetap aman.

Apabila melihat pada tujuan dari sistem peradilan anak yang terdapat pada United Nation Standard Minimum Rules For The Administration Of Juvenile Justice (Beijing Rules) yang tercantum dalam Rules 5.1 sebagai berikut:

20 Children's Hearing Skotland. How Does The Childrens Hearings System Work. Retrieved from www.chscotland.gov.uk/the-childrens-hearings-system/how-does-the-childrenshearings-system-work/ 
"The juvenile justice system shall emphasize the well being of the juvenile and shall ensure that any reaction to juvenile offenders shall always be in proportion to the circumtances of both the offenders and the offence."(Sistem peradilan bagi anak harus lebih mengutamakan kesejahteraan anak dan memastikan bahwa reaksi apapun terhadap pelanggar-pelanggar hukum anak dengan keadaan yang sesuai bagi anak dan pelanggaran hukumnya).

Dapat dikatakan bahwa Children's Hearing System ini merupakan salah satu ide pembaharuan pemerintah Skotlandia demi mencapai sistem peradilan pidana anak yang memperhatikan kesejahteraan anak dan prinsip proporsionalitas (The Principle of Proportionality. Selain itu, sebagai suatu kebijakan untuk menangani masalah perkara anak yang tidak terlepas dari upaya untuk menanggulangi kejahatan anak, Children's Hearing System tidak hanya menjangkau upaya represif saja dimana upaya penanggulangan kejahatan yang menitikberatkan pada sifat pemberantasan dan penumpasan sesudah kejahatan itu terjadi. Akan tetapi juga menjangkau upaya preventif dimana upaya penanggulangan kejahatan yang lebih menitik beratkan kepada sifat pencegahan/penangkalan/pengendalian sebelum kejahatan itu terjadi. Hal ini dapat terlihat dimana di Children's Hearing System tidak hanya menangani anak-anak yang bermasalah dengan polisi saja tapi juga anak-anak yang dikhawatirkan keselamatannya, anak-anak yang bermasalah di sekolah, serta anak-anak yang dikhawatirkan tidak dirawat dengan baik di rumahnya. Dengan begitu tindakan pencegahan sebagai faktor-faktor kondusif yang berpusat pada masalah-masalah atau kondisi-kondisi sosial yang secara langsung dapat menimbulkan kejahatan dapat dihindari.

Berdasarkan hal diatas, dengan adanya kebijakan Children's Hearing System ini sangat membantu dalam hal upaya menyelesaikan perkara anak dan penanggulangan perkara anak sehingga dapat dijadikan sebagai upaya untuk mengoptimalkan sistem peradilan pidana anak di indonesia. Children Hearing System ini dapat diimplementasikan sebagai ide pembaharuan dalam sistem peradilan pidana anak di Indonesia, karena pada dasarnya ruang lingkup pembaharuan sistem hukum pidana di Indonesia terdiri dari substansi hukum, budaya hukum dan struktur hukum yang semuanya harus tidak bertolak belakang dari ide dasar sistem hukum pidana nasional, yaitu keseimbangan ide dasar Pancasila (nilai-nilai Pancasila sebagai landasan sistem hukum nasional) dan keseimbangan tujuan pembangunan nasional.

Children Hearing System sendiri memiliki 3 (tiga) ide dasar, yaitu ketuhanan, humanis dan kemasyarakatan. Tiga ide dasar dari Children Hearing System sesuai dengan ide pembaharuan sistem peradilan pidana anak di Indonesia, terutama pembaharuan dalam aspek budaya hukum. Pembaharuan dalam aspek budaya hukum merupakan perwujudan dari sistem nilai-nilai budaya hukum (filsafat hukum, asas-asas hukum, teori hukum, ilmu hukum dan kesadaran atau sikap perilaku hukum). Oleh karena pembaharuan sistem peradilan pidana anak dalam aspek budaya hukum juga merupakan perwujudan dari ilmu hukum pidana, terutama ilmu hukum pidana nasional yang berlandaskan Pancasila, sehingga memiliki ide keseimbangan dalam nilai religius/ketuhanan, nilai kemanusiaan/humanistik, nilai kemasyarakatan (nasionalistik/demokratik-kerakyatan/keadilan sosial).

Tiga ide dasar dari Children Hearing System ini sesuai dengan nilai-nilai Pancasila sila pertama adalah karena dalam pelaksanaan Children Hearing System tidak akan 
memberikan perlakuan yang berbeda bagi anak hanya karena perbedaan keyakinan yang dimiliki anak, tetapi hanya dilihat dari keadaan fisik dan mental anak demi tercapainya kesejahteraan anak. Children Hearing System sesuai dengan nilai-nilai Pancasila, sila kedua karena dalam pelaksanaan Children Hearing System anak akan diperlakukan sebagaimana mestinya sesuai dengan harkat dan martabatnya sebagai makhluk ciptaan Tuhan yang memiliki hak dan kewajiban yang sama, anak juga akan diajarkan untuk menjunjung tinggi nilai-nilai kemanusiaan, diajarkan untuk memiliki rasa solidaritas dan tenggang rasa yang tinggi agar ke depannya anak tidak berbuat sewenang-wenang. Sesuai dengan nilai-nilai Pancasila, sila ketiga, keempat dan kelima karena dalam pelaksanaan Children Hearing System tidak akan membeda-bedakan anak secara derajat dan golongan, meyakini bahwa semua anak memiliki derajat yang sama di depan hukum seperti halnya orang dewasa, pendampingan, pembimbingan dan pembinaan dilakukan dengan cara kekeluargaan dan akan bersikap adil dan bijaksana dalam mengambil keputusan yang terbaik untuk anak.

\subsection{Children's Hearing System Sebagai Upaya Untuk Mencapai Restorative Justice Di Dalam Sistem Peradilan Pidana Anak Di Indonesia.}

Istilah sistem peradilan pidana anak merupakan terjemahan dari istilah "The Juvenile Justice System", yaitu suatu istilah yang digunakan sedefinisi dengan sejumlah institusi yang tergabung dalam pengadilan, yang meliputi polisi, jaksa penuntut umum dan penasihat hukum, lembaga pengawasan, pusat-pusat penahanan anak, dan fasilitasfasilitas pembinaan anak ${ }^{21}$. Sistem Peradilan Pidana Anak adalah keseluruhan proses penyelesaian perkara anak yang berhadapan dengan hukum, yang dimulai dari tahap penyelidikan sampai pada tahap pembimbingan setelah menjalani masa pidana.

Gordon Bazemore menyatakan bahwa tujuan dari sistem peradilan pidana anak (SPPA) berbeda-beda sesuai dengan paradigma sistem peradilan pidana anak yang dianut ${ }^{22}$. Tiga paradigma anak yang paling terkenal antara lain adalah paradigma pembinaan individual (individual treatment paradigm), paradigma retributive (retributive paradigm), dan paradigma restoratif (restorative paradigm).

Children Hearing System ini sesuai dengan paradigma restoratif (restorative paradigm) yang dikenalkan oleh Gordon Bazemor. Tujuan Sistem peradilan Pidana Anak dengan paradigma restoratif adalah bahwa dalam mencapai tujuan penjatuhan sanksi, maka diikutsertakan korban untuk berhak aktif terlibat dalam proses peradilan ${ }^{23}$. Tujuan penjatuhan sanksi tercapai dengan dilihat pada apakah korban telah direstorasi, kepuasan korban, besar ganti rugi, kesadaran pelaku atas perbuatannya, jumlah kesepakatan perbaikan yang dibuat, kualitas pelayanan kerja dan keseluruhan proses yang terjadi. Bentuk-bentuk sanksi yaitu: restitusi, mediasi pelaku-korban, pelayanan korban, restorasi masyarakat, pelayanan langsung pada korban atau denda restoratif ${ }^{24}$. Restorative Justice tidak mengedepankan efek jera bagi pelaku, tetapi mengedepankan

21 Wahyudi, S. Op.Cit, h. 35 (dalam Djamil, M. N. (2013). Anak Bukan Untuk Dihukum: Catatan Pembahasan UU Sistem Peradilan Pidana Anak (UU-SPPA). Jakarta: Sinar Grafika, h. 43

22 Ibid, h. 45

23 Djamil, M. N. (2013). Anak Bukan Untuk Dihukum: Catatan Pembahasan UU Sistem Peradilan Pidana Anak (UU-SPPA). Jakarta: Sinar Grafika, h. 46

24 Ibid, h. 47 
kesadaran pelaku terhadap tanggung jawab dari perbuatan yang telah dilakukan. Restorative Justice menempatkan nilai yang lebih tinggi dalam keterlibatan yang langsung dari para pihak. Korban mampu untuk mengembalikan unsur kontrol, sementara pelaku di dorong untuk memikul tanggung jawab sebagai sebuah langkah dalam memperbaiki kesalahan yang disebabkan oleh tindak kejahatan atau dalam membangun sistem nilainya. ${ }^{25}$ Keadilan restoratif (Restorative Justice) atau peradilan berbasis musyawarah merupakan suatu proses Diversi, yaitu semua pihak hak yang terlibat dalam suatu tindak pidana tentu bersama-sama mengatasi masalah serta menciptakan suatu kewajiban untuk membuat segala sesuatunya menjadi lebih baik dengan melibatkan korban, anak, dan masyarakat dalam mencari suatu solusi untuk memperbaiki, rekonsiliasi, dan menenteramkan hati yang tidak berdasarkan pembalasan. Keadilan restoratif dalam penyelesaian tindak pidana yang dilakukan oleh anak sangat peduli dalam membangun kembali hubungan setelah terjadinya tindak pidana, daripada memperparah keretakan antara pelaku, korban dan masyarakat yang merupakan karakter sistem peradilan pidana modern saat ini. ${ }^{26}$

Pada saat ini sistem peradilan pidana anak di Indonesia menganut paradigma Restoratif, sehingga sistem peradilan pidana anak di Indonesia dapat juga dikenal sebagai "Restorative Justice System" sesuai dengan ketentuan yang ada pada Undang-Undang Nomor 11 Tahun 2012 tentang Sistem Peradilan Pidana Anak (UU SPPA).

Restorative Justice atau keadilan Restoratif adalah sebuah teori yang menekankan pada pemulihan kerugian yang disebabkan atau ditimbulkan oleh perbuatan pidana. Pemulihan kerugian ini akan tercapai dengan adanya proses-proses kooperatif yang mencangkup semua pihak yang berkepentingan. ${ }^{27}$ Restorative justice adalah pemikiran yang merespon pengembangan sistem peradilan pidana dengan menitikberatkan kepada kebutuhan pelibatan masyarakat dan korban yang dirasa tersisihkan dengan mekanisme yang bekerja pada sistem peradilan pidana yang ada pada saat ini. Tony Marshall menyatakan:28

"Restorative justice is a process whereby all the parties with a stake in a particular offense come together to resolve collectively how to deal with the offermath of the offense and its implications for the future." (Keadilan restoratif adalah proses dimana semua pihak yang terlibat dalam suatu pelanggaran tertentu datang bersama-sama untuk menyelesaikan secara kolektif bagaimana menghadapi akibat dari pelanggaran dan implikasinya untuk masa depan).

Sistem peradilan pidana anak yang menganut konsep keadilan restoratif atau Restorative Justice System pada saat penjatuhan sanksi akan mengikutsertakan pelaku, korban,

25 Yustia, RD.D.A. (2013). Penerapan Restorative Justice Terhadap Orang Tua Pelaku Perdagangan Anak dalam Perspektif Sistem Peradilan Pidana Indonesia. Jurnal Ilmu Hukum Litigasi, 14(1), h. 1861.

26 Ernis, Y. (2016). Diversi dan Keadilan Restoratif dalam Penyelesaian Perkara Tindak Pidana Anak di Indonesia. Jurnal Ilmiah Kebijakan Hukum, 10(2), h. 172.

27 Yunus, Y. (2013). Analisis Konsep Restorative Justice melalui sistem Diversi dalam Sistem Peradilan Pidana Anak di Indonesia, Jurnal Rechts Vinding Media Pembinaan Hukum Nasional, 6(2), h. 234.

28 Makarao, T. (2013). Pengkajian Hukum Tentang Penerapan Restorative Justice dalam PenyelesaianTindak Pidana yang dilakukan Oleh Anak-anak. Badan Pembinaan Hukum Nasional Kementrian Hukum dan HAM RI, h. xxvi 
masyarakat dan para penegak hukum secara aktif. Karakteristik peradilan restoratif adalah "Just Peace Principle" atau keadilan yang dilandasi perdamaian (Peace) antar pelaku, korban, dan masyarakat, sehingga peradilan ini melihat bahwa kejahatan adalah sebagai tindakan oleh pelaku terhadap orang lain atau masyarakat dari pada terhadap negara. ${ }^{29}$ Dalam konsep keadilan restoratif pencapaian dari tujuan-tujuan ini hanya dapat dilakukan melalui suatu mekanisme dialog antara korban dan pelaku serta pelibatan unsur masyarakat. ${ }^{30}$ Pelaku bekerja aktif untuk memperbaiki kerugian yang dialami oleh korban dan juga menghadapi korban atau wakil korban. Korban juga berperan aktif dalam segala tahapan dan membantu dalam penentuan sanksi bagi pelaku. Masyarakat berperan sebagai mediator yang mendukung korban dan mendukung pemenuhan kewajiban pelaku. Penegak hukum berperan sebagai fasilitator selama mediasi tengah berlangsung.

Konsep Restorative Justice bagi anak yang berhadapan dengan hukum dipandang baik untuk diterapkan dalam sistem peradilan pidana anak. Restorative Justice dalam sistem peradilan pidana anak bertujuan untuk menghindarkan anak dari pemidanaan dan digantikan dengan pembimbingan. Melalui pendekatan restorative justice diharapkan pemulihan bagi korban dapat terealisasi, tujuan pemidanaan bagi pelaku akan berhasil dan ketertiban masyarakat pun dapat tercapai. Restorative justice rnerupakan salah satu alternatif untuk mewujudkan keadilan sesuai dengan tujuan hukum. Keadilan yang akan diperoleh semua pihak, baik pelaku, korban maupun masyarakat. ${ }^{31}$

Sesuai dengan Teori Netralisasi oleh Syeks dan Matza, yang menyatakan bahwa orangorang berperilaku jahat atau menyimpang disebabkan adanya kecenderungan di kalangan mereka untuk merasionalkan norma-norma dan nilai-nilai. (yang seharusnya berfungsi sebagai pencegah perilaku jahat) menurut persepsi dan kepentingan mereka sendiri. Menurut Syeks dan Matza, merupakan orang-orang yang gagal meminta maaf atas perbuatannya (Apologetic Failure) dan mengikuti arus gaya hidup para pelaku kejahatan lainnya, melalui proses pembenaran kelakuannya. ${ }^{32}$

Syeke dan Matza merinci bentuk atau kecenderungan penetralisasian di kalangan para pelaku kejahatan yakni:33

\section{The Danial Of Responsibility}

yakni mereka menganggap dirinya sebagai korban tekanan-tekanan sosial, misalnya kurang kasih sayang, pergaulan serta lingkungan kurang baik dan sebagainya.

2. The Denial Of Injury

Yakni mereka menganggap perbuatannya tidak mengakibatkan kerugian besar di masyarakat.

3. The Denial Of The Victim

29 Prayitno, K.P. (2012). Restorative Justice Untuk Peradilan Di Indonesia (Perspektif Yuridis Filosofis dalam Penegakkan Hukum In Concreto). Jurnal Dinamika Hukum, 12(3), http://dx.doi.org/10.20884/1.jdh.2012.12.3.116. h.419

30 Zulfa, E.A. (2010). Keadilan Restoratif dan Revitalisasi Lembaga Adat di Indonesia. Jurnal Kriminologi Indonesia, 6(2), h. 202.

31 Yulia, R. (2009). Restorative Justice Sebagai Alternatif Perlindungan Hukum Terhadap Korban Kekerasan Dalam Rumah Tangga. Jurnal Hukum dan Pembangunan, 39(2), h. 248.

32 Hadisuprapto, P. (2010). Delinkuensi Anak Pemahaman dan Penanggulangannya. Malang: Selararas, h. 21

33 Ibid, h. 22. 
Yakni mereka menyebut diri mereka adalah pahlawan.

4. Condemnation of the condemners

Yakni mereka menganggap bahwa orang yang mengutuk mereka adalah orang yang munafik, hipokrit atau pelaku kejahatan terselubung.

5. Appeal to higher Loyality

Yakni mereka merasa dirinya terperangkap antara kemauan masyarakat luas dan hukumnya dengan kebutuhan kelompok kecil atau minoritas dari mana mereka berasal atau minoritas dimana mereka berasal atau tergabung.

Sampai saat ini di Indonesia, salah satu variasi mekanisme restorative justice adalah sistem diversi. Diversi adalah pengalihan penyelesaian perkara anak dari proses peradilan pidana ke proses di luar peradilan pidana. Tidak jauh berbeda dengan konsep Children Hearing system yang bertujuan untuk mengalihkan atau mengeluarkan anak pelaku tindak pidana dari sistem peradilan pidana. Sejatinya Children hearing system sudah diatur di dalam sistem peradilan pidana anak khususnya di dalam UndangUndang Nomor 11 Tahun 2012 Tentang Sistem peradilan Pidana dalam bentuk Diversi akan tetapi, Perbedaan diversi dengan Children Hearing system ini adalah bahwa dalam Children hearing system tidak ada sanksi bagi anak, yang ada hanyalah Perintah Pengawasan Wajib dan anak masih dapat tetap tinggal di rumah.

Apabila negara Indonesia mampu menerapkan sistem Children Hearing seperti negara Scotlandia, maka hal ini dapat menjadi terobosan atau hal baru dalam sistem peradilan pidana anak Indonesia yang sedang menggunakan paradigma Restorative Justice, karena dalam pelaksanaannya dilakukan secara kekeluargaan yang dapat dilaksanakan oleh anak yang bermasalah dengan hukum $(\mathrm{ABH})$, orang tua anak, anggota panel yang terdiri dari masyarakat, psikolog anak dan juga dinas pekerja sosial.

Children Hearing system ini merupakan upaya baru yang jauh lebih dekat untuk mencapai tujuan dari Restorative Justice System. Children Hearing system juga dapat menjangkau upaya Preventif dalam mencegah anak melakukan suatu tindakan yang melawan hukum. Hal ini dikarenakan di dalam Children's Hearing tidak hanya menjangkau anak yang bermasalah dengan polisi (Hukum) tapi juga anak yang bermasalah di sekolah atau anak yang tidak dirawat dengan baik di rumah karena lingkungan merupakan salah satu faktor anak melakukan suatu tindakan yang melanggar hukum. Baik itu lingkungan keluarga maupun lingkungan sosialnya. Terlebih lagi, Children Hearing system juga menjangkau semua anak yang mengalami tindak kejahatan terhadap anak.

Children's Hearing system ini merupakan proses peradilan pidana anak yang edukatif karena tidak harus melukai perkembangan jiwa anak akibat dari stigmatisasi atau labeling. Hampir sama dengan diversi, akan tetapi yang membedakan adalah di dalam Children's Hearing ada upaya preventif dalam menanggulangi masalah anak. Seperti yang telah dijelaskan sebelumnya bahwa anak yang dibawa ke Children's Hearing tidak hanya anak yang bermasalah dengan polisi (hukum), anak yang memiliki masalah di sekolah dan anak tidak dirawat dengan baik oleh orang tuanya, tetapi juga anak dari korban kejahatan itu sendiri. Hal ini merupakan upaya preventif agar mereka tidak terjerumus untuk melakukan hal-hal yang melanggar hukum. Hal ini mungkin dapat di jadikan salah satu contoh untuk diterapkan di Indonesia. 
Walaupun diversi telah dilaksanakan di indonesia tapi tidak menjangkau upaya-upaya preventif. Oleh karena itu penting kiranya kita untuk mempertimbangkan menambahkan children hearing ini dalam sistem peradilan pidana kita. Mungkin tidak keseluruhan, akan tetapi kita ambil mengenai upaya-upaya preventif tersebut.

\section{Kesimpulan}

Children Hearing System adalah sistem perawatan dan keadilan khas Skotlandia untuk anak-anak dan remaja. Ini bertujuan untuk memastikan keamanan dan kesejahteraan anak-anak dan remaja yang rentan melalui pengambilan keputusan tribunal yang disebut Panel Anak-Anak. Children's Hearing System merupakan usaha untuk mencapai Restorative Justice untuk menanggulangi masalah anak pelaku tindak pidana, karena di dalam Children's Hearing hak-hak asasi manusia anak diutamakan. Indonesia sendiri dikenal dengan Diversi. Hampir sama dengan Diversi, akan tetapi yang membedakan adalah di dalam Children's Hearing ada upaya preventif dalam menanggulangi masalah anak. Hal ini dapat terlihat dari anak yang dibawa ke Children's Hearing tidak hanya anak yang bermasalah dengan polisi (hukum), tapi juga anak yang memiliki masalah di sekolah dan anak tidak dirawat dengan baik oleh orang tuanya. Hal ini merupakan upaya preventif agar mereka tidak terjerumus untuk melakukan hal-hal yang melanggar hukum. Hal ini mungkin dapat menjadi Ide Pembaharuan dalam Sistem Peradilan Pidana Anak di Indonesia. Ide Children's Hearing System ini dapat di implementasikan di dalam pembaharuan sistem peradilan pidana anak di Indonesia. Hal ini karenakan di dalam Children Hearing System sendiri memiliki 3 (tiga) ide dasar, yaitu ketuhanan, humanis dan kemasyarakatan yang sesuai dengan ide pembaharuan sistem peradilan pidana anak di Indonesia, terutama pembaharuan dalam aspek budaya hukum. Children Hearing system ini merupakan upaya baru yang jauh lebih dekat untuk mencapai tujuan dari Restorative Justice System. Children Hearing system juga dapat menjangkau upaya preventif dalam mencegah anak melakukan suatu tindakan yang melawan hukum. Sistem peradilan pidana anak di Indonesia yang masih menggunakan sistem diversi masih dirasa kurang sehingga akan lebih baik jika pemerintah Indonesia dapat belajar dari sistem peradilan pidana anak di Skotlandia yang menerapkan Children hearing system yang sifatnya lebih fleksibel serta memasukkan Children hearing system ini ke dalam Sistem Peradilan Pidana Anak di Indonesia.

\section{Daftar Pustaka}

\section{$\underline{\text { Buku }}$}

Djamil, M. N. (2013). Anak Bukan Untuk Dihukum: Catatan Pembahasan UU Sistem Peradilan Pidana Anak (UU-SPPA). Jakarta: Sinar Grafika.

Gultom, M. (2008). Perlindungan Hukum terhadap anak dalam sistem peradilan pidana anak di indonesia. Bandung: Refika Aditama.

Hadisuprapto, P. (2010). Delinkuensi Anak Pemahaman dan Penanggulangannya. Malang: Selararas.

Makarao, T. (2013). Pengkajian Hukum Tentang Penerapan Restorative Justice dalam PenyelesaianTindak Pidana yang dilakukan Oleh Anak-anak. Jakarta: Badan Pembinaan Hukum Nasional Kementrian Hukum dan HAM RI. 
Marlina. (2012). Peradilan Pidana Anak Di Indonesia, Pengembangan Konsep Diversi dan Restorative Justice. Medan: PT Refika Aditama.

Nashriana. (2011). Perlindungan hukum pidana bagi anak di Indonesia. Jakarta: RajaGrafindo Persada.

Wahyudi, S. (2011). Implementasi Ide Diversi Dalam Pembaharuan Sistem Peradilan Pidana Anak Di Indonesia. Yogyakarta: Genta Publishing.

\section{Jurnal}

Ernis, Y. (2017). Diversi Dan Keadilan Restoratif Dalam Penyelesaian Perkara Tindak Pidana Anak di Indonesia (Diversion And Restorative Justice In Case Settlement Of Juvenile Justice System In Indonesia). Jurnal Ilmiah Kebijakan Hukum, 10(2), 163-174. http://dx.doi.org/10.30641/kebijakan.2016.V10.163-174

Fathurokhman, F. (2013). Undang-Undang Sistem Peradilan Anak, Pelajaran dari Kearifan Lokal dan Kasus Raju. Kanun: Jurnal Ilmu Hukum, 15(2), 339-356.

Norrie, K. (2000). Human rights challenges to the children's hearing system. Journal of the Law Society of Scotland, 45(4), 19-21.

Prayitno, K. (2012). Restorative Justice untuk Peradilan di Indonesia (Perspektif Yuridis Filosofis dalam Penegakan Hukum In Concreto). Jurnal Dinamika Hukum, 12(3), 407-420. http://dx.doi.org/10.20884/1.jdh.2012.12.3.116

Rochaeti, N. (2015). Implementasi Keadilan Restoratif Dan Pluralisme Hukum Dalam Sistem Peradilan Pidana Anak Di Indonesia. Masalah-Masalah Hukum, 44(2), 150160. http://dx.doi.org/10.14710/mmh.44.2.2015.150-160

Sari, M.A.C.M (2013). Diversi Dalam Sistem Peradilan Pidana Anak di Indonesia. Jurnal Magister Hukum Udayana (Udayana Master Law Journal). 2(1). https://doi.org/10.24843/JMHU.2013.v02.i01.p05

Suharto, G. R. (2015), Restorative Justice Peradilan Pidana Anak di Indonesia. Lex Crimen, 4(1). 35-45.

Yulia, R. (2009). Restorative Justice Sebagai Alternatif Perlindungan Hukum Terhadap Korban Kekerasan Dalam Rumah Tangga. Jurnal Hukum \& Pembangunan, 39(2), 238-254.

Yunus, Y. (2013). Analisis Konsep Restorative Justice Melalui Sistem Diversi Dalam Sistem Peradilan Pidana Anak Di Indonesia. Jurnal Rechts Vinding: Media Pembinaan Hukum Nasional, 2(2), 231-245.

Yustia, D. A. (2013). Penerapan Restorative Justice Terhadap Orang Tua Pelaku Perdagangan Anak dalam Perspektif Sistem Peradilan PIdana Indonesia. Jurnal Ilmu Hukum LITIGASI, 14(1).

Wahyudi, S. (2009). Penegakan Peradilan Pidana Anak dengan Pendekatan Hukum Progresif dalam Rangka Perlindungan Anak. Jurnal Dinamika Hukum, 9(1), 29-39. http://dx.doi.org/10.20884/1.jdh.2009.9.1.52

Zulfa, E.A. (2010). Keadilan Restoratif dan Revitalisasi Lembaga Adat di Indonesia. Jurnal Kriminologi Indonesia, 6(2). 


\section{Website}

Children's Hearing Skotland. How Does The Childrens Hearings System Work. Retrieved from www.chscotland.gov.uk/the-childrens-hearings-system/howdoes-the-childrens-hearings-system-work/

Children's Hearing Skotland, Retrieved from http://www.chscotland.gov.uk/thechildrens-hearings-system /

\section{Peraturan Perundang-undangan}

Undang-Undang Dasar 1945

Undang-Undang Nomor 11 Tahun 2012 tentang Sistem Peradilan Pidana Anak

United Nations Standard Minimum Rules for the Administration of Juvenile Justice ("The Beijing Rules") Adopted by General Assembly resolution 40/33 of 29 November 1985 Part one. 